\title{
THREE HUNGARIAN DIPLOMATS' EMISSARY DIARIES - A COMPARATIVE ANALYSIS OF EMISSARY DIARIES OF JÁNOS RIMAY, GÁSPÁR TASSY AND MIHÁLY THOLDALAGI IN THE CONTEXT OF THE 1627 PEACE TREATY OF SZÖNY ${ }^{1}$
}

\author{
Gellért E. Marton
}

http://orcid.org/0000-0002-9732-0312

MTA-SZTE Research Group of the Ottoman Age (ELKH), Szeged (Hungary)

\begin{abstract}
The article focuses on the examination of three emissary diaries related to the Peace Treaty of Szöny (1627). These sources differ considerably from the most widespread sources used in the diplomatic history. The diaries were published earlier but have not been systematically compared yet. These diaries approach the treaty from different perspectives even though they touch upon the same affair. The emissaries arrived to the peace talks with various mandates, resided in different places, and exchanged their correspondence with different persons, thus gaining access to the same pieces of information at different times and/or in different places. Therefore, it is reasonable to pose
\end{abstract}

1 The research related to this paper was supported by the Ministry of Human Capacities (Emberi Erőforrások Minisztériuma) through the grant (code no. 20391-3/2018/FEKUSTRAT), by the Bilateral State Scholarship subsidised by the Tempus Public Foundation (Tempus Közalapítvány, Államközi Ösztöndij). This paper is written as a contribution of the Interdisciplinary Centre of Excellence, the Department of Medieval and Early Modern Hungarian History (Faculty of Humanities and Social Sciences) (University of Szeged), and the MTA-SZTE Research Group of the Ottoman Age. I am grateful to Sándor Papp (Head of the MTA-SZTE Research Group of the Ottoman Age) who provided useful pieces of advice during the research process and writing of this study. Furthermore, I am really grateful to Katarzyna Kuras, Tomasz Pudłocki and Stanisław Sroka who supported my research activities in Cracow (not exclusively) during the academic year 2018/2019.

This article has already been published in part in Hungarian. The current paper is an enlarged, revised and, as well, updated version of the earlier published study. See the earlier article in Hungarian: G.E. Marton, “'Szőnyből tudatjuk...’. Három magyar diplomata - Rimay János, Tassy Gáspár és Tholdalagi Mihály - követnaplóinak összehasonlító elemzése az 1627. évi szőnyi békekötés kapcsán" [in:] Oszmán-magyar viszony a 16-18. században: Tanulmányok a Magyar Királyság és az Oszmán Birodalom népeinek - magyarok, törökök, rácok, tatárok, zsidók, görögök és egyéb népek hétköznapjairól; Egyén és közösség viszonya, ed. Zs.J. Újváry, Budapest 2020, pp. 135-148. 
the following questions: what kind of information was known by whom in a given moment; which specific aspect of the peace talks was concerned; who could exert an influence on the process; and, respectively, how and for what purpose the pieces of information were retrieved from a participant; or how these pieces of information were used by those who belonged to the participant's network of relations.

Keywords: Peace Treaty of Szőny (1627), negotiations at Szécsény and Buda (1628), Mihály Tholdalagi, Gáspár Tassy, János Rimay, Miklós Esterházy, Dániel Esterházy, István Sennyei, Pasha Murteza, Habsburg-Ottoman peace treaties, emissary diaries, deep reading, comparative analysis.

The aim of this paper is to examine the results of a part of a formerly started source collecting activity in connection with the Habsburg-Ottoman Peace Treaty of Szőny in 1627. In this case it means three emissary diaries, written by Mihály Tholdalagi, Gáspár Tassy and János Rimay, by comparing them. The systematic collection of the related sources was launched earlier. ${ }^{2}$

We should note that the historical research into peace treaties, the inquiry into Habsburg-Ottoman peace treaties, in particular, is not a novel trend. Numerous historical disciplines have already investigated the development of international peace processes, by simultaneously applying various viewpoints. The emissary diary, a genre that flourished during the Early Modern Age, is to be adapted to this discourse as a subjective narrative source. These sources are considerably different from the widespread use of conventional diplomatic historical sources (e.g. correspondences, records, credentials) because of these contain not only notes about the official events, but also show us the process from a viewpoint which is different from the others. It is worth mentioning, beside the others, that these are not memoires, the notes of the diaries were recorded at the time of the peace process. So, unsurprisingly, these three diaries had been published earlier. ${ }^{3}$ However, they have not been systematically compared so far. In this article I focus on the examination of the aforementioned three diaries related to the 1627 Peace Treaty of Szőny.

Thus, the aim is to contrast the contents of these documents in order to interpret the peace process from a new viewpoint. This comparative analysis is just a component of a systematically built-up methodological toolbar employed by our research group. ${ }^{4}$ The aforementioned activities and this article fit into the same research pro-

2 It started in 2014 within the framework of source reading seminar at the Doctoral School of History (University of Szeged). The author of this article joined to this in 2015. This activity developed under the leadership of Professor Sándor Papp (DSc) and in the summer of 2017 a specific historical research into Habsburg - Ottoman peace treaties was launched under the name of MTA-SZTE Research Group of the Ottoman Age. The Research Group is funded by the Hungarian Academy of Sciences. The aim of the Research Group is to collect the ratified items of the Habsburg-Ottoman peace treaties and then to study the full texts of the documents relevant of each peace treaty between the two empires.

3 F. Salamon, Két Magyar diplomata a tizenhetedik századból, Pest 1867; S. Eckhardt (ed.), Rimay János összes müvei, Budapest 1955.

4 The comparison of these three diaries is part of the research in connection with the Peace Treaty of Szőny (1627). Approximately 2,000 letters (correspondences, instructions, reports) was collected by our research group which were written by various participants of the peace process. A significant part of them is unpublished. From these documents the members of the research group have already published 
ject and their common aim is to show what quantity and quality of scientific research could be achieved on the field of the historical inquiry into peace treaties. ${ }^{5}$

It is remarkable that the three diaries are available in connection with one peace process, but they become truly important through the persons of three diarists and their role in the peace process. So, it is worth mentioning who the three diarists were. Mihály Tholdalagi ${ }^{6}$ was Gábor Bethlen's ${ }^{7}$ envoy, the loyal servant of the Prince of Transylvania, during his service he was sent to Constantinople on several occasions. Tholdalagi's diary is the longest, it is a diary and at the same time a collection of letters, because he copied into his diary all of the letters which were written by him and were sent to him, or which were in his hands for some reason. Beside these, he also recorded several verbal messages and summaries of his discussions which contain useful additional information in relation to the peace process. His diary started on March 11, 1627 and ended on August 18. The second is Gáspár Tassy, ${ }^{8}$ who was the secretary of Miklós Esterházy, ${ }^{9}$ the Palatine of Hungary. Tassy was sent by the Palatine to act chiefly as an envoy if serious and complicated diplomatic situations emerged. Gáspár Tassy went to Buda when the commissioners fell out with each other and the negotiations were suspended. ${ }^{10}$ His diary covered the shortest period, from July 18 to August $11 .{ }^{11}$ The third diarist is János Rimay ${ }^{12}$ who was one of the greatest Hungarian Renaissance poets and he had a remarkable political and diplomatic career

a selection which shows with the help of hitherto unpublished documents an overview of the peace process (G. Brandl, Cs. Göncöl, K. Juhász, G.E. Marton, J. Szabados, "Válogatott források az 1627. évi szőnyi békeszerződés történetéhez," LYMBUS 2017, pp. 151-203). The aforementioned letters were entered into a database which we are developing and expanding with new data. With the help of this database we conducted quantitative analyses with respect to the participants' diplomatic networks and the vital as well as intensive periods of the peace process (G. Brandl, Cs. Göncöl, K. Juhász, G.E. Marton, J. Szaba do s, "Kommunikáció és híráramlás. A Habsburg-oldal tárgyalási stratégiája az 1627. évi szőnyi békekötés során," Aetas 2018, no. 4, pp. 108-124; furthermore: G. Brandl, Cs. Göncöl, K. Juhász, G.E. Marton, J. Szabados, "Kommunikation und Nachrichtenaustausch wärend des Friedensprozesses von Szőny (1627) Im Spiegel der verhandlungsstrategien der Habsburger," Chronica 2020, pp. 113-140. The already accomplished tasks are the forerunners of the monographic processing of this peace treaty by the research group.

5 For more about the research group's activity and its size, see: S. Papp, “Az Oszmán Birodalom, a Magyar Királyság és a Habsburg Monarchia kapcsolattörténete a békekötések tükrében (Vázlat és adatbázis)," Aetas 2018, no. 4, pp. 86-99.

6 For Mihály Tholdalagi's life and diplomatic activity, see: I. Nagy, Magyarország családai czimerekkel es nemzedékrendi táblákkal, I-XIII, Pest 1853-1867, XI, p. 148.

7 Prince of Transylvania, r. 1613-1629.

8 For his life and role in detail, see: F. Salamon, Két Magyar diplomata, pp. XXXIX-XLIV.

9 Count Miklós Esterházy of Galántha, the Palatine of Hungary, his time in office: 1625-1645.

10 F. Salamon, Két Magyar diplomata, p. XLI.

11 It is worth mentioning that the length of Tassy's diary is only the third of Tholdalagi's, but the time span covered by the Transylvanian envoy's diary is five times longer than that of the other.

12 For more about Rimay's diplomatic and political activity, see: S. Papp, Török szövetség Habsburg kiegyezés. A Bocskai-felkelés történetéhez, Budapest 2014, passim; Magyar Müvelödéstörténeti Lexikon, Budapest 2010. vol. X, pp. 103-108 (the entry edited by P. Ács); T. Klaniczay (ed.), A magyar irodalom története, vol. II. (from 1600 to 1772), Budapest 1964, pp. 16-17. 
as well. Rimay was delegated to the negotiations as the emissary of Nógrád County. His diary started on May 25 and ended on August 1. His diary is the shortest.

The participation of the counties' representatives is important because this was the first time when the Hungarian counties had had a possibility to send their emissaries with a list of the goods stolen and destroyed by the Ottomans. The no. XXIX article of 1625 which was issued by the Hungarian Diet declared that the counties, which were territorially involved in terms of the negotiations and the new peace treaty, had a right to send their emissaries to inform the negotiators about the losses. It may be worth continuing the collection of these type of sources due to the nature and content of their instructions and records. Not just Nógrád County was the only one which sent their representative to the peace negotiations. On April 12, 1627, Palatine Miklós Esterházy addressed a letter to diet of Győr County and ordered them to send their emissary with a list about the county's grievances. ${ }^{13}$

Beside these examples we could mention the deputy-bailiff of Bars County, Imre Liptay, who was an emissary of the Hungarian party's negotiators, delegated to Buda during the peace process. Later he participated in the territorial negotiations which started on January $12,1628,{ }^{14}$ where the question of the villages of the borderland were discussed. He was delegated there as the emissary of Bars County. ${ }^{15}$ In the same place János Rimay was also present, but as Gömör County's emissary. In a letter written by the Palatine on December 31, 1627 the names of the counties' representatives were recorded. ${ }^{16}$ As it has been mentioned above, the diaries were published earlier, so it is worth examining them in greater depth. Thus, it is important to discuss some methodological issues.

Beside the three diaries, I used Pál Jászay’s work on the Peace Treaty of Szőny, published in $1838 .{ }^{17} \mathrm{He}$ provided a comprehensive overview, based on the available materials. It needs to be noted that I do not intend to compare this work with the three diaries, I only use the information and the sources expounded in that work. For example, Jászay published Nógrád County's instruction ${ }^{18}$ and there is no information about the original instruction, so it is only Jászay's work that contains details of it. It

13 Miklós Esterházy's letter, addressed to the diet of Györ County, Kismarton, April 12, 1627, K. Ráth, “Gróf Esterházy Miklós levelei,” Magyar Történelmi Tár 1861, ser. I, no. 8, pp. 12-13.

14 F. Salamon, Két Magyar diplomata, p. 286. In connection with the territorial negotiations in 1628 , see: F. Salamon, L. Szalay, Galánthai Gróf Eszterházy Miklós. Magyarország nádora, vol. I-III, Pest 1863-1870; J. Stes se1, “Adatok az 1628. évi szécsényi alkudozás történetéhez I-II," Magyar Történelmi Tár 1902, no. 3, pp. 430-452, pp. 481-510; G.E. Marton, "On the Question of the Negotiations Between the Habsburgs and the Ottomans at Szécsény and Buda (1628) through Palatine Miklós Esterházy’s Letter to the Head of the Hungarian Negotiators," Rocznik Przemyski 2019, vol. 55, Historia, 1 (22), pp. 79-91.

15 For the instruction sent to him by Ferdinand's commissioners, see: G. Brandl, Cs. Göncöl, K. Juhász, G.E. Marton, J. Szabados, "Válogatott források," pp.165-168.

16 The name of the emissaries who were delegated to the territorial negotiations can be found in a letter written by Miklós Esterházy on December 31, 1627. Bars County: Imre Liptay, Hont County: Horváti György, Gömör County: Rimay János, Nógrád County: Fanch[i/y] Ferencz, Pest-Pilis, Solt and Heves Counties: Bakó Ferencz. A. Ipolyi, Alsósztregovai és Rimai Rimay János államiratai és levelezése, Budapest 1887, p. 304 (doc. no. CLI).

17 P. Jászay, “A’ szőnyi béke. 1627,” Tudománytár, Értekezések 1838, no. 4, pp. 167-274.

18 Ibidem, pp. 216-226. 
is worth mentioning that Pál Jászay failed to write into his work the provenience of the sources which were published by him. He published several sources which we have not seen yet in original, for example, the aforementioned instruction issued by diet of Nógrád County.

Thus, the above-mentioned three diaries and Jászay's work were taken into a fourcolumn table, sorted by dates. But why is it useful and how could one use this table? Through these works it is possible to observe the peace process from different perspectives. With the help of the method known as deep reading, one has a chance to collect and compare information and view the peace process from further individual perspectives. This well-known reading method can help us better understand all the circumstances and observe each thing from different viewpoints. What is more, some parts of the events could be presented richer in detail, than if we observed these works as separate ones. For instance, under the date of June 18, János Rimay noted only that he, Márton Apáczai, Pál Budai and the Ottoman commissioners were expedited to find the most appropriate place for the negotiations between Szöny ${ }^{19}$ and Komárom. ${ }^{20}$ Jászay wrote that the Ottoman commissioners arrived in Szöny and listed them by name. ${ }^{21}$ Under this date the third record is written by Mihály Tholdalagi. This is the most detailed one. By Gáspár Tassy there is not any record because his commission started one month later. Tholdalagi's detailed record about this event mentioned that he arrived with the Ottomans, in possession of the Habsburg party's proposal about the place of the negotiations and the Ottoman party's response as well. He listed several names, like Zsigmond Eörsi, whose name was not mentioned by Rimay. However Tholdalagi failed to record Rimay's name. ${ }^{22}$ Consequently, we could get a more detailed picture if we compared the records together.

With the help of the aforementioned deep reading one could find examples how the information flow operated, and about the network of relations, too. Moreover, a plausible question is what kind of information was known by whom in a given moment, about which specific aspect of the peace talks, who could exert influence on the process, and, respectively, how and for what purpose the pieces of information retrieved from a participant, or that information how was used by those who belonged to the participant's network of relations. The data, letters and letter references one could find in the diaries are closely related to each other. ${ }^{23}$ The discussed diaries help us in the research process on various fields, for instance in the data gathering, sometimes even in the dating of letters. Therefore, we could not only study the dia-

19 Present day the village of Szőny is part of Komárom, in Hungary.

20 S. Eckhardt (ed.), Rimay János, p. 418.

${ }_{21}$ Isza Effendi Mufti of Buda [budai mufti], Mehmet Pasha of Eger, Achmet Bey of Esztergom, Moharrem Bey of Szolnok, Dzsiha Agha of the Azabs of Buda [budai azabok agája]. P. Jászay, “A' szőnyi béke," pp. 207-208.

22 F. Salamon, Két Magyar diplomata, pp. 85-86.

23 The diaries and Jászay's work contain almost 150 letters and letter references and dozens of names of the peace process' participants. 
ries separately, but together with the aforementioned materials (e.g. correspondence), with the help of the well-known method, the so-called deep reading. ${ }^{24}$

For instance, on July 27, Gáspár Tassy noted in his diary that during his discussion with Pasha Murteza, ${ }^{25}$ he showed that the letter had been written by Gábor Bethlen before Murteza was appointed to the Pasha of Buda. Therefore, that content was not known by him. It should be noted that the letters were not copied into the diary. Because those letters had been sent from the Palatine's record office and after Tassy's mission, his diary were taken into the hands of Miklós Esterházy. After that the Pasha had read the letters he said that he would have Bethlen strangled at the Porte. ${ }^{26}$ Two days later Tholdalagi wrote to Chancellor István Sennyei ${ }^{27}$ that Agha Habib informed him about the letters having been written to the Porte and to Karakás ${ }^{28}$ (former Pasha of Buda) and his successors. Habib thought that mischief was planned against the Prince of Transylvania at the Palatine's Court. ${ }^{29}$ Sennyei in his response, addressed to Tholdalagi, wrote that Tassy did not write so much in the letter which was sent to Chancellor. ${ }^{30}$ In contrast to this, János Rimay took a long record about what had been presented by Tassy to the Pasha and what Murteza's responses were. ${ }^{31}$ After these events Chancellor Sennyei wrote to the Transylvanian envoy that it is pointless to continue the negotiations before Tassy arriving back from Buda to Szőny, but István Sennyei would willingly discuss for some reason with Tholdalagi. ${ }^{32}$ Rimay also recorded that the Ottomans wanted to urge the other party to continue the negotiations. During these two days Tassy noted that he was busy over letter-writing, and interpreters of the Pasha of Buda were engaged in letter-translation. ${ }^{33}$

The topics of Jászay's work together with the three diaries unfold the peace process. The recorded topics and events provide a survey that allows us to better understand of the negotiations.

Now let us see the discussed topics of the peace process. The correspondence mentioned the place of the negotiations but through the emissaries' viewpoints the importance of choosing the negotiations' place could be better understood. The participants paid more attention to selecting the negotiator's tent they should have the meetings and discussions, or they need to find a neutral area between their camps,

${ }^{24}$ Here, it is worth mentioning that the author of this article intends to publish the critical edition of Tassy's and Tholdalaghi's diary.

25 The Pasha of Buda, 1626-1630. Cf. A. Gévay, A'budai pasák, Vienna 1841, p. 29.

26 Ibidem, pp. 203-211.

27 István Sennyei of Kis-Sennye (ar. 1580-1635) - Bishop of Vác and Hungarian Chancellor from 1623. Cf. G. Brand1, Cs. Göncöl, K. Juhász, G.E. Marton, J. Szabados, “Kommunikáció és híráramlás," pp. 120-121.

28 The Pasha of Buda, 1618-1621. Cf. A. Gévay, A’budai pasák, p. 26.

29 Ibidem, pp. 154-155.

30 Ibidem.

31 S. Eckhardt (ed.), Rimay János, pp. 421-423.

32 F. Salamon, Két Magyar diplomata, pp. 154-155.

33 Ibidem, p. 212. 
than to the peace-making process. ${ }^{34}$ Furthermore, it was also debated who goes to negotiate with whom, or with what kind of military entourage did the commissioners have to arrive at the place of the negotiations..$^{35}$ The diarists recorded the negotiations' seating arrangement. ${ }^{36}$ At the beginning the high commissioners were not seated to face each other. In relation to this, in the diaries an additional problem was also mentioned which originated from the seating arrangement: who could and who could not speak with each other. In the diary of Bethlen's envoy one could find other pieces of information about the negotiations' protocol. For example, Tholdalagi wrote about the status and the role of Transylvania. As the Transylvanian envoy, he had to go to the negotiation together with the Ottoman party. ${ }^{37}$ But why is it relevant? Because the Ottoman and the Habsburg parties did not regard Transylvania as a third negotiator. Transylvania was definitely identified as part of the Ottoman party, despite all the attempts of the Transylvanians. Moreover, Transylvania was mentioned several times. For instance, when the participants of the process were arguing if the Principality should be included into the peace treaty. Palatine Miklós Esterházy sent word to Pasha Murteza about writing Transylvania into the peace treaty separately because there would be peace just between the two Emperors. It also resulted a peaceful and secure position for the Principality of Transylvania, except if Bethlen would do something against that. ${ }^{38}$ The position of Transylvania and Bethlen were presented when Rimay recorded into his diary on July 30 the following: "Pasha Murteza knows that the Prince of Transylvania has a higher rank than the Pasha of Buda, but according to the Sultan's forceful commandment get on the field with his armies to demonstrate his power to achieve better peace conditions." 39 This message shows not just Transylvania's position, but a great example of that the Pasha did everything to enforce the peace from the parties. And for this he wanted to muster the greatest forces as much as he could to avoid the outbreak of a war in the taut situation of those days.

Beside these efforts one could find in the diaries records about private, secret, semi-official and unofficial meetings as well as the timing and the working methods of the negotiations. For instance, Tholdalagi recorded meetings with Dániel Esterházy and István Sennyei. Here, it is worth mentioning that Dániel Esterházy was the Palatine's brother who was delegated to the negotiations by his brother. Sennyei, the Bishop of Vác, was the Hungarian Chancellor and in this case, the high commissioner of the Habsburg party. The Transylvanian envoy mentioned that on one occasion

34 Rimay and Tholdalagi recorded into their diaries on June 18-22, about the negotiations' protocol. F. Salamon, Két Magyar diplomata, pp. 85-94; S. Eckhardt (ed.), Rimay János, p. 418.

35 F. Salamon, Két Magyar diplomata, pp. 102-106.

36 Rimay recorded under the date June 27 that the place of the negotiations was settled. Tholdalagi recorded that the participants agreed in the seating arrangement. S. Eckhardt (ed.), Rimay János, p. 418; F. Salamon, Két Magyar diplomata, pp. 98-100. On July 1, Tholdalagi recorded into his diary the changes in the seating arrangement. From this moment Chancellor István Sennyei and the Mufti of Buda sat vis-à-vis and the Hungarian Chancellor was closer to Tholdalagi. F. Salamon, Két Magyar diplomata, pp. 112-113.

37 F. Salamon, Két Magyar diplomata, pp. 102-106.

38 Ibidem, p. 152.

39 S. Eckhardt (ed.), Rimay János, p. 423. 
Dániel Esterházy found pretext for a private meeting with Tholdalagi to buy a horse..$^{40}$ During this meeting Bethlen's envoy spent much time to convince Esterházy that Gábor Bethlen did not want to detain the delegations from making a new peace. From this viewpoint one could see an example for background negotiations between the Hungarian and the Transylvanian participants. It should also be noted that in this respect Mihály Tholdalagi was the key person. He was the most active among the participants during the period which was covered by the diaries. It is hardly surprising because he had to arrange Transylvania's question. He wanted to enter into further negotiations behind the scenes with Gáspár Tassy as well, but on August 8, his attempt was unsuccessful because Tassy arrived with a Turkish entourage. ${ }^{41}$

As it has been mentioned above, one could find several examples of the timing of the meetings and of the working methods as well. For instance, Mihály Tholdalagi recorded in connection with his negotiations with Dániel Esterházy ${ }^{42}$ and István Sennyei that their meetings and negotiations were between 5 and 11 a.m. ${ }^{43}$ because of the summer weather. One day early in the morning, Sennyei sent a letter to Tholdalagi, who received it just around 9 o'clock, about a meeting. He responded that they should meet in the next morning, when the weather is still cool. ${ }^{44}$ Beside these informal meetings, Tholdalagi's official discussions with Pasha Murteza ${ }^{45}$ were conducted early in the morning as well. On July 13, they went on with the negotiations from 6 to 11 a.m. where they checked the translation of a letter written by Gábor Bethlen. What is more, 10 days later Tassy went to meet with the Pasha at the Divan early in the morning. It is also worth mentioning that before this meeting Tassy had conveyed letters from the Palatine to the Pasha with messages, but the Pasha's interpreter suggested that Tassy convey verbal messages in writing. It was important because sometimes the messages were longer than the letters and because of offering a better understanding and avoiding information loss. In addition to the question of the interpreter, it should be noted that not just the Pasha worked with interpreters. In his letter on September $14^{46}$ Bethlen mentioned that his envoy worked together with an interpreter as well. It means Tholdalagi may not have known Turkish language or not well enough.

40 F. Salamon, Két Magyar diplomata, pp. 168-169.

41 Ibidem, p. 234.

42 Dániel Esterházy of Galántha (1585-1654) - Hungarian aristocrat, Ferdinand II's commissioner at the time of the negotiations of Szöny. G. Brand1, Cs. Göncöl, K. Juhász, G.E. Marton, J. Szabados, "Válogatott források," p. 155.

43 F. Salamon, Két Magyar diplomata, pp. 162-164. For more examples of the discussions early in the morning, see: ibidem, pp. 79-85, 98-100, 130-131. (These aforementioned meetings and discussions in general started at 5-6 a.m. and ended at 11-12 a.m. The timing of these was the same at Szonny and Buda as well.)

44 Ibidem, p. 156.

45 Ibidem, p. 138.

46 M. Sebestyén (Select., Intro. and notes), Bethlen Gábor levelek, Bukarest 1980, pp. 220-226, no. 59 . 
The peace process was not devoid of intrigue, bribe ${ }^{47}$ and putting pressure on each other. For instance, Tassy noted on July 22, while they were on their way to attend the Pasha of Buda, they were escorted on a route so as to see the armies of Pasha Murteza processing. ${ }^{48}$ It was obviously meant as a smart military tour de force to show true mettle. In addition to this, Tassy's descriptions also inform about the Pasha ordering his troops to march to Buda for the annual muster.

With the help of the above-mentioned deep reading one could find examples how the information flow operated, and about the network of relations as well. For instance, Tassy noticed in his diary that he would not have trust Tholdalagi, because he recognised that Bethlen's diplomat missed to inform him about several things. What is more, it later turned out that the Transylvanian envoy had information about some circumstances which he missed to tell to the Palatine's envoy. On July 21, Tassy wrote that he asked why Lázár Horváth was sent to Buda. The respondent said that the copy of the latest peace treaty between Bethlen and the Habsburg Emperor was not transmitted to the agent of the emperor at the Porte in the original form by Questenberg. ${ }^{49}$ The following was added to the original version of peace treaty: the Prince was in allegiance with the Emperor, and Bethlen would become the enemy of its enemy, the friend of its friend, and if need be, Bethlen would attack the Ottomans. The letter of Tamás Borsos (also relating this issue and sent to the Porte) was shown to Tassy. The copy of this was sent to the English and Dutch envoys, its Turkish translation was circulated in Constantinople, bringing shame on the prince.$^{50}$ However, it was not only Tholdalagi who withheld pieces of information. When he invited Tassy, the Palatine's secretary showed the instruction received from Miklós Esterházy but did not reveal the message sent to the Pasha. ${ }^{51}$

Beside the diplomatic acts, one could find a significant amount of evidence on daily life that help understand why sometimes virtually nothing happened for several days. On July 22, Sennyei wrote to Tholdalagi that, on the one hand, he did not want to play for the time being, but his ordainment as a bishop was approaching, so he was obliged to travel to Nagyszombat (present day Trnava in Slovakia) to the Archbishop, Péter Pázmány. On the other hand, he was alone in Komárom, because Dániel Esterházy went home for a short time. Moreover, he wrote that he was lagging behind sending a response because he had to prepare himself to the Mary Magdalene's Day Holy Mass. At the end of July Tholdalagi noted in his diary that he felt bored in Szőny. Among others, one could find entries about hunts, gifts, unbridled carousal, or Tassy recorded that they played backgammon at his quarters in Buda. Moreover, one could find information about sicknesses. From the negotiator Mózes Cziráki, through

47 Tholdalagi mentioned in his record on 2 July that Pál Buday promised him money secretly in order to facilitate the giving over of the fortress of Vác. F. Salamon, Két Magyar diplomata, p. 130.

48 Ibidem, pp. 188-189.

49 Gerhard Questenberg (1586-1646) - member of the Aulic War Council (Hofkriegsrat) from 1626, later vice president of it. G. Brand1, Cs. Göncöl, K. Juhász, G.E. Marton, J. Szabados, "Válogatott források," p. 155.

50 F. Salamon, Két Magyar diplomata, pp. 186-187.

51 Ibidem, pp. 184-185. 
Pasha Murteza to Gábor Bethlen, everybody was sick, and it also got around that the Prince of Transylvania died.

Furthermore, some notes could be found also in connection with the question of war and peace. Pasha Murteza built a palisade at Ercsi ${ }^{52}$ close to Buda, situated on the Danube's bank, which was deemed a good spot for an ambush in times of war..$^{53}$ Although the following is not a note from the diaries, yet Pál Jászay wrote about a letter which also contained information retrieved from Buda. He published a letter dated to May 2, which he originally received from Sennyei in Hungarian, without the name of the sender and the archive where he had found this. It contained information about the Sultan's army being engaged in Persia and having lost 60,000 soldiers. ${ }^{54}$ The letter-writer noticed that the Ottomans had not received any kind of help from Gábor Bethlen, and he also took another note: if the Hungarians formed a league with Ferdinand II against the Ottomans now, they could expulse them from Hungary. What is more, the Hungarian Chancellor did not mention this piece of information to the Transylvanian envoy. In addition to this, it is worth mentioning that not only the Ottoman Sultan was afraid of a two-front war, but the Habsburg Emperor too. Both delegations were forced by their emperors to make peace to avoid the two-front-warsituation. ${ }^{55}$

While the parties prepared themselves for the peace, they paid attention to "keep the powder dry" and there were different offers circulated. The Dutch envoys' manipulation tried to find their way to Buda. As Gáspár Tassy mentioned, they had attempts to ask Pasha Murteza stepping into war against the Habsburgs. ${ }^{56}$ Pasha Murteza's aforementioned annual muster, on the one hand, was an example of preparing for a war, on the other hand as putting pressure and demonstrating his power to enforce the peace.

Over the aforementioned topics, it can be found a long discourse in connection with the bases of the negotiations. Among others one could find the question of the fortress of Vác. About Vác the Pasha clearly stated to Gáspár Tassy on June 25, that he should give Vác over to the Habsburgs after the clash of arms. The Pasha of Buda made it clear to Tassy that the attack would be a bad choice for them because military events would be just on the Hungarians' territory. The Pasha underlined that the troops on the Persian battlefields did not pose any danger to the Ottomans' military power in Hungary, as they had enough troops around. ${ }^{57}$

52 App. 40 kms southwest of Buda.

53 Recorded by Gáspár Tassy on June 29. Ibidem, p. 213.

54 (Great) Abbas Sah (1587-1629) had made considerable successes at the Ottoman-Safavid borderlands. He took Baghdad in 1624 and forced the Ottoman troops sent to relieve the city to withdraw in June 1626. For more about him and his campaign, see: G. Brandl, Cs. Göncöl, K. Juhász, G.E. Marton, J. Szabados, "Kommunikáció és híráramlás," pp. 110-111.

55 F. Salamon, Két Magyar diplomata, pp. 15-22. Imre Karácson published two letters issued by Sultan Murad IV. The first contained that Murad IV invested Pasha Murteza with full power, while the second forced Prince Bethlen to cooperate with the Pasha. I. Karács on, Török-magyar, Budapest 1914, pp. 218-220, 217-218.

56 F. Salamon, Két Magyar diplomata, p. 199.

57 Ibidem, pp. 193-202. 
It should be noted that not just the Ottomans were cautious. The counties' emissaries were informed on June 30, as János Rimay recorded in his diary, that the Habsburg party did not have enough information on whether it will be war or peace. They were asked to be careful, but it did not mean that they must be frightened..$^{58}$ A few days earlier Miklós Esterházy warned Győr County to prepare their troops in case of a war. ${ }^{59}$

The content of the diaries can help better understand the peace process and may also reveal the network of relations of each participant. Additionally, we gain a deeper and more detailed image about their interpersonal network, including their role and importance during the discussed part of the peace process.

This project fits into a greater research framework as one of the components of the systematic endeavours of exploring sources, both published and unpublished. It is neatly complemented by the archival material, since the examination of diaries as a source type means a specific research problematic and provides a challenging methodological task for historians.

\section{BIBLIOGRAPHY}

\section{Primary Sources Published}

Brandl G., Göncöl Cs., Juhász K., Marton G.E., Szabados J., "Válogatott források az 1627. évi szőnyi békeszerződés történetéhez," LYMBUS 2017, pp. 151-203.

Eckhardt S. (ed.), Rimay János összes müvei, Budapest 1955.

Ipolyi A., Alsósztregovai és Rimai Rimay János államiratai és levelezése, Budapest 1887. Jászay P., “A’ szőnyi béke. 1627,” Tudománytár, Értekezések 1838, no. 4, pp. 167-274.

Karácson I., Török-magyar oklevéltár, Budapest 1914.

Marton G.E., "On the Question of the Negotiations Between the Habsburgs and the Ottomans at Szécsény and Buda (1628) through Palatine Miklós Esterházy's letter to the head of the Hungarian negotiators," Rocznik Przemyski 2019, vol. 55, Historia, 1 (22), pp. 79-91.

Ráth K., "Gróf Esterházy Miklós levelei,” Magyar Történelmi Tár 1861, ser. I, no. 8, pp. 3-208.

Salamon F., Két Magyar diplomata a tizenhetedik századból, Pest 1867.

Salamon F., Szalay L., Galánthai Gróf Eszterházy Miklós. Magyarország nádora, vol. IIII, Pest 1863-1870.

Sebestyén M. (Select., Intro. and notes), Bethlen Gábor levelek, Bukarest 1980.

Stessel J., “Adatok az 1628. évi szécsényi alkudozás történetéhez I-II," Magyar Történelmi Tár 1902, no. 3, pp. 430-452, pp. 481-510.

\footnotetext{
58 S. Eckhardt (ed.), Rimay János, p. 428.

59 Palatine Miklós Esterházy's letter to the diet of Győr County. On June 24, 1627, at Lakompak, published: K. Ráth, “Gróf Esterházy Miklós,” pp. 14-16.
} 


\section{Literature}

Brandl G., Göncöl Cs., Juhász K., Marton G.E., Szabados J., "Kommunikáció és híráramlás. A Habsburg-oldal tárgyalási stratégiája az 1627. évi szőnyi békekötés során,” Aetas 2018, no. 4, pp. 108-124.

Brandl G., Göncöl Cs., Juhász K., Marton G.E., Szabados J., "Kommunikation und Nachrichtenaustausch wärend des Friedensprozesses von Szőny (1627) Im Spiegel der verhandlungsstrategien der Habsburger," Chronica 2020, pp. 113-140

Gévay A., A'budai pasák, Vienna 1841.

Klaniczay T. (ed.), A magyar irodalom története, vol. II. (from 1600 to 1772), Budapest 1964.

Magyar Müvelödéstörténeti Lexikon, Budapest 2010. vol. X (the entry edited by P. Á c s).

Nagy I., Magyarország családai czimerekkel es nemzedékrendi táblákkal, I-XIII, Pest 1853-1867, XI.

Papp S., “Az Oszmán Birodalom, a Magyar Királyság és a Habsburg Monarchia kapcsolattörténete a békekötések tükrében (Vázlat és adatbázis),” Aetas 2018, 4, pp. 86-99.

Papp S., Török szövetség - Habsburg kiegyezés. A Bocskai-felkelés történetéhez, Budapest 2014. 